\title{
52. Effects of Depressants and Hypothermia on the Protein Metabolism in Nerve Cell Body of the Rat Cerebral Cortex in vivo
}

\author{
By Mei Satake, Sachiko Abe, and Shigeko Araki \\ Brain Research Institute, Niigata University \\ (Comm. by Masahiro OKadA, M. J. A., April 12, 1974)
}

Under anaesthesia the rate of protein metabolism of the whole brain decreases and hypothermia accelerates the extent of this decrease (Gaitonde and Richter, 1956). A rather slight increase in the labelling of the liver protein was observed in the same experiments.

In order to correlate the function and the metabolism of macromolecules in the brain, it seems essential to isolate neurons.

The objective of the present experiments was to determine which cells, neuron or glia, or both may be influenced by narcotics using a method (Satake and Abe, 1966) which can provide a large amount of cellular protein labelled in vivo.

Materials and methods. Rats of Wistar strain weighing about $100 \mathrm{~g}$ were used throughout the experiments. The nerve cell body, the interfacial material and the cerebral cortex were prepared from the control and anaesthetized animals according to the method of Satake and Abe (1966) as follows. Each animal was killed by decapitation at the scheduled time after the intraperitoneal injection of $5 \mu \mathrm{Ci} / 100 \mathrm{~g}$ body weight of ${ }^{14} \mathrm{C}$-labelled algal protein hydrolysate $(0.1 \mu \mathrm{Ci} / 0.77 \mathrm{mg}$, Radiochemical Centre, Amersham, England). This intraperitoneal injection of labelled amino acids was carried out about 30 min after the animal had been anaesthetized. Cerebral cortices free from the white matter and pia were cut into small pieces, kept in 20 volumes of acetone-glycerol-water (1:1:1, by volume) for 30 min, and then homogenized very gently by hand in 5 volumes of glycerol- $0.25 \mathrm{M}$ sucrose (3:1, by volume). The filtrate through a flannel cloth was diluted with 5 volumes of the Ringer-Locke solution and centrifuged at 2,000 r.p.m. for $15 \mathrm{~min}$. The precipitate suspended in $0.5 \mathrm{M}$ sucrose was layered over 2 volumes of $1.75 \mathrm{M}$ sucrose and spun at 14,500 r.p.m. for $30 \mathrm{~min}$ in a SW-25 swinging rotor. Two fractions, transparent bottom pellet and cloudy interphase between the two sucrose layers were obtained. The bottom pellet consisted of an almost pure mass of nerve cell bodies. Trichloroacetic acid insoluble proteins of these fractions and of the chopped and thoroughly mixed cerebral cortex were purified, and the radioactivity of these 
proteins was measured by a gasflow counter and expressed as count per min (c.p.m.) per mg protein after correction by the self-absorption as reported earlier (Satake and Abe, 1966).

Ether anaesthesia was carried out in a large desiccator ventilated with oxygen which passed through a layer of ether. Urethan, amobarbital or phenobarbital was given intraperitoneally at doses of $0.15 \mathrm{~g}, 10 \mathrm{mg}$ or $20 \mathrm{mg}$ per $100 \mathrm{~g}$ body weight respectively, and whenever necessary, additional doses were given to keep the animal anaesthetized. Anaesthesia was carried out in a laboratory room of about $10-15^{\circ} \mathrm{C}$ or in temperature-controlled rooms of $9-11^{\circ} \mathrm{C}$ or 28 $30^{\circ} \mathrm{C}$. The anal temperature of the animal was measured with a thermister.

Results. Yield and morphology of cell fractions. The bottom pellet was identified to be an almost pure mass of nerve cell body, 7-25 $\mu$ in diameter and having a pale and round nucleus. The interfacial material was shown to be mixture of glial cell or glial cell body having a dark and small nucleus, myelin and other granular materials of unknown origin with small number of entrapped nerve cell body in it. About one to three millions of the nerve cell bodies were collected from the cerebral cortices of a rat. No differences in the yield and the appearance by phase-microscopy were observed between the cell fractions of the control and anaesthetized rats.

The time course of incorporation of the labelled amino acid into the proteins of cell fractions and cerebral cortex under anaesthesia. Fig. 1 shows the time course of the protein-bound radioactivities of the cell fractions and of the cerebral cortex of the control animals and those of the anaesthetized animals. About $2 \mathrm{hrs}$ after the intraperitoneal injection of the labelled amino acids the radioactivity reached a maximum in the control animals. Under ether anaesthesia, similar tendency of labelling was observed until $2 \mathrm{hrs}$ after injection except at the early phase of labelling and the specific radioactivity of the nerve cell body was the highest at all the times examined in both the control and anaesthetized animals.

Ratio of the specific activity of proteins of the cell fractions to that of the cerebral cortex under anaesthesia 2 hrs after the injection of labelled amino acids. Table I shows the specific activities of the proteins of the cell fractions and the cerebral cortex of the normal rat $2 \mathrm{hrs}$ after the intraperitoneal injection of algal protein hydrolysate and the per cent ratio relative to that of cerebral cortex. Specific activities of each fraction and the cerebral cortex were variable between experimental groups. However, when the specific activities within each experiment were expressed as per cent ratios of the specific activity of the cell fractions to that of the cerebral cortex from 


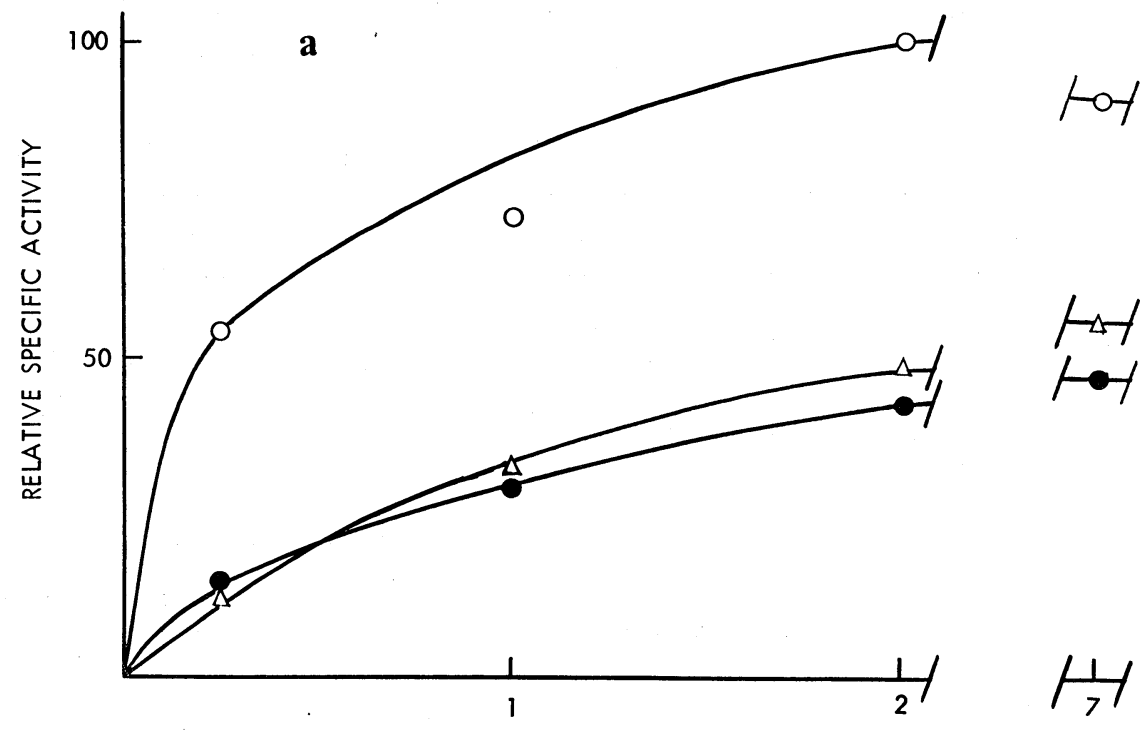

TIME AFTER ISOTOPE INJECTION (HOURS)

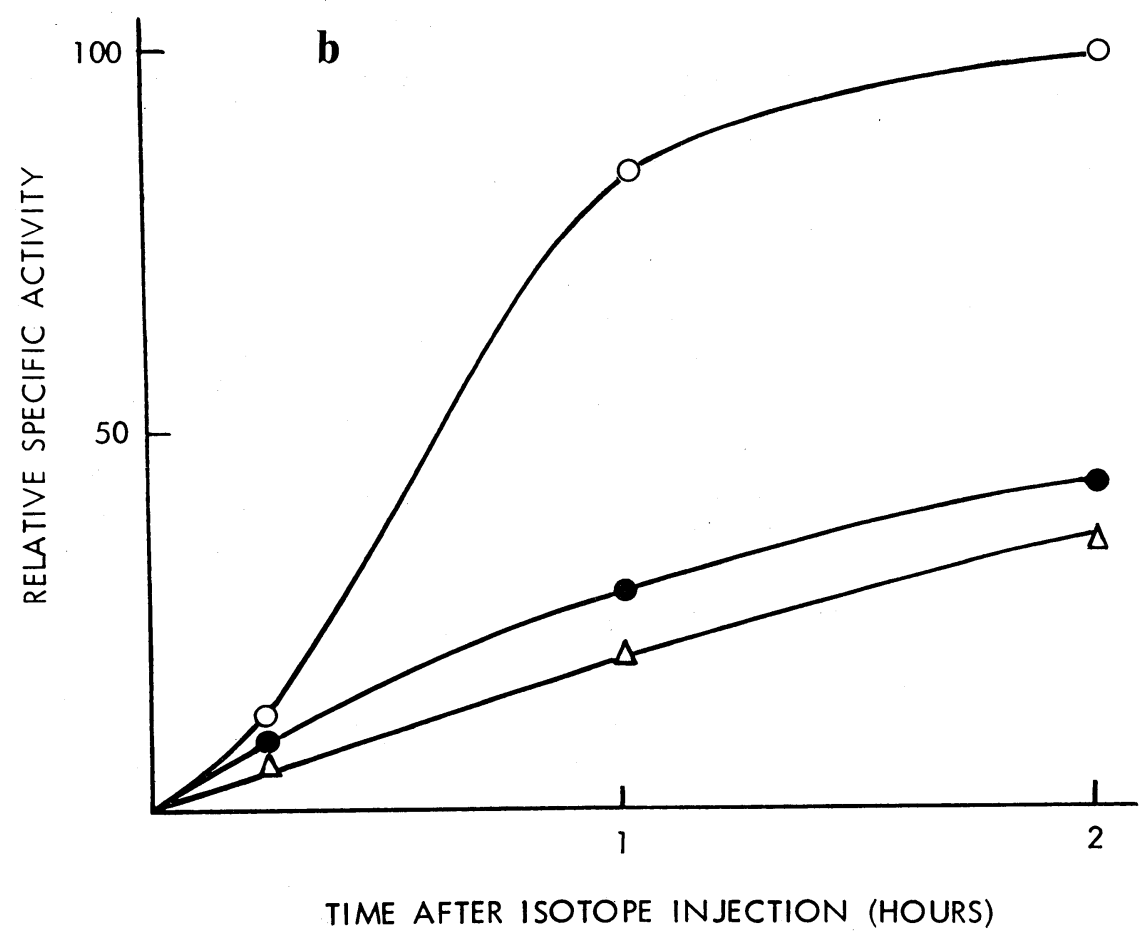

Fig. 1. Time course of the incorporation of labelled amino acid mixture into proteins of nerve cell body $(O)$, interfacial fraction $(\triangle)$ and cerebral cortex (•) of rat in vivo. Values represent percentage to the nerve cell body at 120 min. a: control rats, b: anaesthetized rats. 
Table I. Protein-bound radioactivity of cerebral cortex, nerve cell body and interfacial fraction of normal rat $2 \mathrm{hrs}$ after intraperitoneal injection of ${ }^{14} \mathrm{C}$-algal protein hydrolysate

\begin{tabular}{|c|c|c|c|c|c|}
\hline \multirow{2}{*}{ Exp. No. } & \multicolumn{3}{|c|}{$\begin{array}{l}\text { Specific radioactivity } \\
\text { counts } / \mathrm{min} / \mathrm{mg} \text { protein }\end{array}$} & \multicolumn{2}{|c|}{$\begin{array}{l}\% \text { to specific activity } \\
\text { of cerebral cortex }\end{array}$} \\
\hline & $\begin{array}{l}\text { Cerebral } \\
\text { cortex }\end{array}$ & $\begin{array}{l}\text { Nerve } \\
\text { cell body }\end{array}$ & $\begin{array}{l}\text { Interfacial } \\
\text { fraction }\end{array}$ & $\begin{array}{l}\text { Nerve } \\
\text { cell body }\end{array}$ & $\begin{array}{l}\text { Interfacial } \\
\text { fraction }\end{array}$ \\
\hline 1 & 69 & 149 & 81 & 213 & 117 \\
\hline 2 & 45 & 107 & 53 & 236 & 116 \\
\hline 3 & 49 & 78 & 47 & 159 & 98 \\
\hline 4 & 67 & 121 & 85 & 182 & 128 \\
\hline 5 & 49 & 98 & 47 & 202 & 98 \\
\hline 6 & 46 & 107 & 46 & 231 & 100 \\
\hline 7 & 54 & 89 & 43 & 165 & 80 \\
\hline Mean & & & & 198 & 105 \\
\hline S.D. & & & & \pm 31 & \pm 16 \\
\hline
\end{tabular}

Table II. Effects of narcotics on incorporation of labelled amino acids into proteins of nerve cell body, interfacial fraction and cerebral cortex of rat

\begin{tabular}{|c|c|c|c|c|}
\hline \multirow{2}{*}{$\begin{array}{c}\text { Narcotics used } \\
\text { (Number of experiment) }\end{array}$} & \multicolumn{2}{|c|}{ Nerve cell body } & \multicolumn{2}{|c|}{ Interfacial fraction } \\
\hline & Mean \pm S.D. & $\mathrm{P}$ & Mean \pm S.D. & $\mathrm{P}$ \\
\hline $\begin{array}{c}\text { Control } \\
(7)\end{array}$ & $198 \pm 31$ & & $105 \pm 16$ & \\
\hline $\begin{array}{l}\text { Ether } \\
\text { (6) }\end{array}$ & $274 \pm 57$ & $0.05>$ & $114 \pm 15$ & $>0.05$ \\
\hline $\begin{array}{l}\text { Urethan } \\
\text { (3) }\end{array}$ & $310 \pm 37$ & $0.01>$ & $121 \pm 9$ & $>0.05$ \\
\hline$\underset{(4)}{\text { Amobarbital }}$ & $281 \pm 38$ & $0.01>$ & $109 \pm 12$ & $>0.05$ \\
\hline $\begin{array}{l}\text { Phenobarbital } \\
\text { (4) }\end{array}$ & $271 \pm 29$ & $0.01>$ & $108 \pm 6$ & $>0.05$ \\
\hline
\end{tabular}

Results for each of narcotics were expressed as mean of percent and standard deviation of the protein-bound specific activity of nerve cell body and interfacial fraction to that of the cerebral cortex in each experiment. The values for $\mathrm{P}$ give statistical significance of differences from respective control values.

which the cell fractions had been obtained, it was evident that the specific activity of the nerve cell body was about two times higher than that of the cerebral cortex and this ratio was fairly constant throughout the experiments.

Under anaesthesia by four kinds of narcotics, the ratio of the specific activity of protein of the nerve cell body to that of the cerebral cortex was approximately 3, as shown in Table II, whereas that of the protein of the interfacial fraction to that of the cerebral cortex remained unchanged.

The series of experiments mentioned above was carried out without controlling the body temperature of the experimental animals 
Table III. Effect of body temperature during anaesthesia on labelling of proteins of nerve cell body, interfacial fraction and cerebral cortex of rat

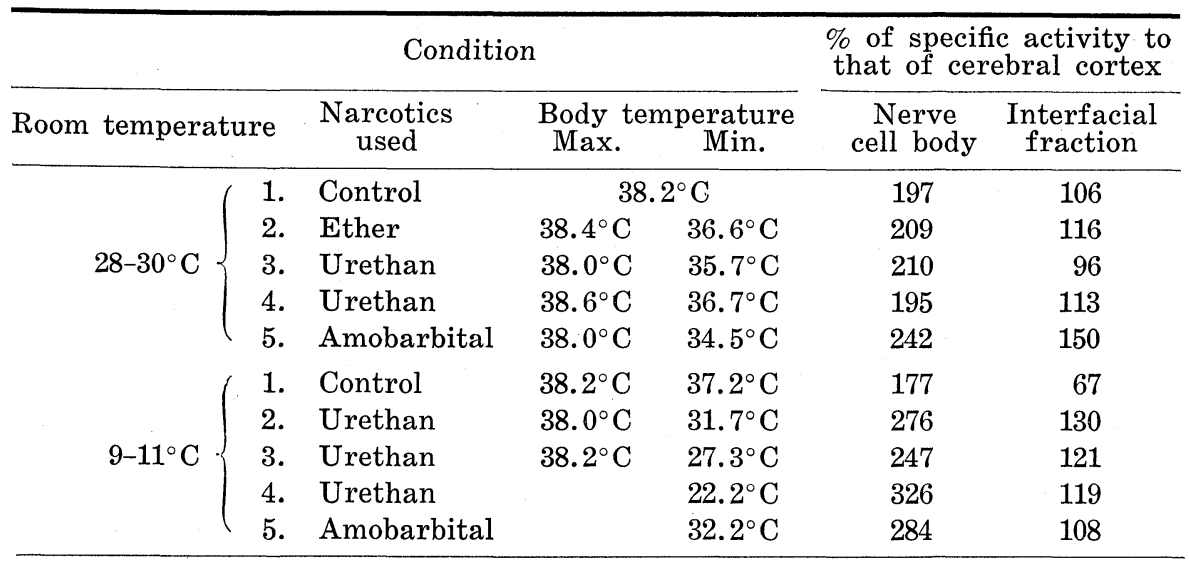

The mean, standard deviation and $\mathrm{P}$ in two groups were $214 \pm 20$ and $>0.05$ in $28-30^{\circ} \mathrm{C}$ group and $284 \pm 33$ and $0.01>$ in $9-11^{\circ} \mathrm{C}$ group for the nerve cell body. For the interfacial fraction they were $118 \pm 23$ and $>0.05$ in $28-30^{\circ} \mathrm{C}$ group and $120 \pm 9$ and $>0.05$ in $9-11^{\circ} \mathrm{C}$ group.

in a laboratory room of fairly low temperature (about $10-15^{\circ} \mathrm{C}$ ). Table III shows the specific activity ratio when the body temperature was kept low or high during anaesthesia by carrying out the experiment in a room of cold $\left(9-11^{\circ} \mathrm{C}\right)$ or hot $\left(28-30^{\circ} \mathrm{C}\right)$ temperature. The results imply that under anaesthesia, the ratio of the specific activity of protein of the nerve cell body to that of the cerebral cortex approximated 3 in hypothermia, whereas it corresponded to the value of the control animal (about 2) at normal temperature.

Discussion. In the present experiment with anaesthetics, it was shown that when animals were kept normothermic the ratio of the specific activity of the protein of the nerve cell body to that of the whole cerebral cortex was two. In those kept hypothermic, the rate of the amino acid incorporation into the whole cerebral cortex was shown to decrease more markedly than in the former cases (Gaitonde and Richter, 1956), the ratio of the specific activity of the protein of nerve cell body to that of the whole cerebral cortex or that of the interfacial fraction was found to approximate 3.

These phenomena will be explained as follows: under anaesthesia and the normothermic condition, the rate of the incorporation of amino acid, given intraperitoneally, into the protein of nerve cell body of the rat brain decreased to nearly the same degree as that of the whole cerebral cortex, and under the hypothermic condition the anaesthetics caused a rather larger decrease in the nerve cell body 
than that in the whole cerebral cortex, and furthermore the hypothermia lowered the rate of the axoplasmic transport of the protein newly synthesized in the nerve cell body, resulting in the modification of the ratio of specific activity of the protein of the nerve cell body to that of the whole cerebral cortex, to be close to three. Velocity of the axoplasmic flow of the protein decreased at low temperature in the frog sciatic nerve (Abe, Haga and Kurokawa, 1972; Edström and Hanson, 1973). The time course of the labelling of the protein of the nerve cell body under anaesthesia (Fig. 1b) at $10-15^{\circ} \mathrm{C}$ of room temperature supports the above explanation. Namely, in Fig. $1 \mathrm{~b}$, at $15 \mathrm{~min}$ after isotope injection the relative specific activity of the protein of the nerve cell body was very low and close to that of the whole cerebral cortex in contrast to that of the control animals suggesting the lowered protein synthetic activity of the neuron, and later on the relative specific activity of the protein of the nerve cell body increased steeply compared to that of the control animal or the whole cerebral cortex of the anaesthesized animal probably due to accumulation of the newly synthesized protein in the nerve cell body.

\section{References}

Abe, T., Haga, T., and Kurokawa, M.: Bulletin of the Japanese Neurochemical Society, 11, 107 (1972).

Edström, A., and Hanson, M.: Brain Res., 58, 345 (1973).

Gaitonde, M. K., and Richter, D.: Proc. Roy. Soc. B., 145, 83 (1956).

Satake, M., and Abe, S.: J. Biochem., 59, 72 (1966). 